\title{
ПРОМОВИСТІ ІМЕНА В ІДІОСТИЛІ ДЕНА БРАУНА ЯК ПРОБЛЕМА ПЕРЕКЛАДУ
}

У статті здійснено аналіз способів передачі промовистих імен персонажів у творчості Дена Брауна в українськомовних перекладах. Розглянуто переваги та недоліки цих методів із метою виявлення ключових проблем, 3 якими стикаються перекладачі під час відтворення антропонімікону творів письменника. Автор статті наголошує, що використання промовистих імен персонажів є однією із визначальних рис ідіостилю Дена Брауна, творчий метод якого полягає у створенні інтелектуальної гри між автором та читачем, атмосфери загадковості та таємничості, а також у наданні символічного змісту зображуваним явищам. Промовисті імена містять вказівку на долю, характер персонажа або навіть на розв'язання загадки цілого твору. На основі перекладів творів Дена Брауна “Код да Вінчі” та "Інферно" такими українськими перекладачами, як В. К. Горбатько, А. Б. Кам'янець та С. А. Кононенко, основними засобами передачі промовистих імен персонажів у творах письменника визначено транскрипцію та транслітерацію, які дозволяють досягти адекватного перекладу. Зроблено висновок про те, що адекватність такого перекладу полягає у створенні балансу між формою та значенням антропоніма, оскільки в деяких випадках просто неможливо одночасно зберегти і форму, і змістове наповнення одиниці. Ця ситуація призводить до того, що перекладач постає перед дилемою: з одного боку, транскрипції / транслітерації недостатньо для повного відтворення промовистого імені, тому що “закодовані” в ньому смисли можуть бути втрачені, а з іншого - перекладач не може обмежитися лише передачею значення одиниці, оскільки це призведе і до втрати форми, і до прирощування додаткових смислів або спотворення ідіостилю автора. Дослідження акцентує увагу на тому факті, що кожне із промовистих імен, використаних Деном Брауном - це загадка для читача, яку перекладач повинен передати і читачеві твору мовою перекладу. Зроблено висновок про те, що українські перекладачі усвідомлюють це, однак вимушені жертвувати частиною закладених в іменах смислів заради збереження основного художнього задуму письменника.

Ключові слова: антропонім, загадка, смислове навантаження, транскрипція, транслітерація, форенізація.

Вступ. Ден Браун активно послуговується значним шаром ономастичної лексики, зокрема й в одному із заголовків (The Da Vinci Code), що вже є підставою вважати вживання таких лексичних одиниць однією 3 характерних рис індивідуальної манери письменника. O. В. Ревзіна [24] зазначає, що словник власних назв в індивідуальних образах відтворює активну пам'ять автора, що охоплює історію, культуру та географію [24, с. 272]. Особливої уваги власні назви у творчості Дена Брауна заслуговують і з огляду на той факт, що символізм імен персонажів є однією із визначальних рис ідіостилю письменника, оскільки він завжди ретельно підбирає їх і надає їм внутрішнього смислу, а це й зумовлює актуальність вивчення проблеми відтворення таких власних назв.

Постановка проблеми та аналіз попередніх досліджень і публікацій. Пропоноване дослідження присвячене вивченню промовистих імен в ідіостилі популярного американського письменника XXI ст. Дена Брауна як проблеми перекладу. 3 одного боку, власні назви неконотативні, тобто вони називають предмет, але не надають йому жодних якостей i характеристик, тому їх не можна перефразувати та перекласти [1, с. 190]. 3 іншого боку, художня література нерідко використовує промовисті імена для конотативних характеристик своїх персонажів. Ю. О. Карпенко зазначає, що не існує більш вдячного мовного матеріалу для художньо-стилістичного використання, ніж власні назви з огляду на їхню здатність містити в собі незміряний, величезний обсяг інформації [16, с. 68]. Функційне навантаження літературних онімів, зокрема антропонімів, ретельно дослідили Л. Л. Белей [2], О. А. Бірюкова [8], Д. Лампінг [17], Є. С. Отін [25]. На думку дослідників, ім'я є результатом осмислення автором внутрішньої сутності персонажа, його ролі в розвитку сюжету, воно може характеризувати героя за вчинками, поведінкою, зовнішнім виглядом, вказувати на національність, регіон, у якому він проживає. В аспекті перекладу мовознавці неодноразово розглядали промовисті імена, в житі в казково-фантастичних творах $[14 ; 15 ; 26]$. У своїх працях лінгвісти наголошують на важливості перекладу значення таких антропонімів та знаходженні адекватного відповідника, водночас збереження форми вони вважають вторинним завданням. Однак практика демонструє, що таке збереження не завжди можливе, оскільки смисли, закодовані в антропонімах, не завжди доступні

(C) Черник O., 2020 
читачеві, який належить до іншої культури. Тому дотримання форми або змісту антропоніму $є$ індивідуальним рішенням перекладача, оскільки такі асоціативні зв'язки в деяких випадках можуть проходити повз його увагу, або ж перекладач стикається 3 певними обмеженнями, продиктованими авторським стилем та конкретним твором.

Незважаючи на значну кількість праць, присвячених мовним особливостям творів Дена Брауна [9; 13; 18; 19; 22], проблема перекладу промовистих імен в його детективах досі не знаходила свого відображення у роботах вітчизняних мовознавців. 3 огляду на вищевказані факти мета статті - вивчення основних проблем передачі промовистих імен персонажів у творчості Дена Брауна в українськомовних перекладах. Мета передбачає розв'язання таких завдань: 1) проаналізувати змістове навантаження імен персонажів у творах письменника; 2) розглянути способи відтворення авторських антропонімів в українськомовних перекладах творів Дена Брауна; 3) визначити головні труднощі під час перекладу промовистих імен.

Методи та методики дослідження. Для розв’язання поставлених завдань використано загальнонаукові методи аналізу і синтезу та спеціальні лінгвістичні дослідницькі методи компонентного, етимологічного та семантичного аналізу, а також перекладознавчі методи, зокрема трансформаційного аналізу.

Результати та дискусії. Антропоніміка є частиною ономастики, вона вивчає систему особових імен (індивідуальні імена, імена по батькові, прізвища, прізвиська, псевдоніми тощо) [27]. Вибір способу перекладу антропонімів, безперечно, залежить від стилю та жанрових особливостей текстів, у яких вони трапляються [21, с. 135]. У більшості випадків процес передачі власного імені іншою мовою складно назвати перекладом як таким, оскільки, як правило, оніми транскрибуються або транслітеруються [28]. Проте в художніх творах імена завжди виділяються на тлі всього тексту й привертають чималу увагу. Крім номінативної функції, вони виконують низку інших, що допомагає письменникові втілити художній задум. Зокрема, як зазначає Т. Є. Некряч, “у багатьох творах імена не обігруються в тексті, проте чимало говорять читачеві оригіналу, оскільки утворюють асоціативний шлейф” [20]. У випадку наявності у творі промовистого імені виникає потреба в пошуку його відповідника в цільовій мові, який буде відтворювати семантико-функційне навантаження оригінального антропоніма.

Особливості відтворення антропонімічної лексики в українськомовних перекладах романів Дена Брауна зумовлені походженням власних імен, які використовує письменник. Це можуть бути як антропоніми, створені на основі імен або прізвищ реальних людей, так $\mathrm{i}$ антропоніми із зашифрованим “прихованим сенсом”, який читач повинен декодувати.

Зокрема, групу антропонімів з ім'ям / прізвищем реальної людини очолює в художньому світі Д. Брауна Robert Langdon [6] - головний герой циклу романів. Як пояснює сам письменник, він дав прізвище персонажеві на честь Джона Ленгдона (John Langdon), творчістю якого захоплювався і який створив амбіграми для “Янголів і демонів" [11]. Окрім того, прізвище містить лексему-суфіксоїд -don, що позначає викладача в університеті, - зазвичай у Кембриджі та Оксфорді [11]. Персонаж $є$ професором не менш престижного університету - Гарвардського. Оскільки ім'я запозичене від людини з реального світу, таке ім'я достатньо відтворити засобами практичної транскрипції - Роберт Ленгдон [4; 5]. У такий спосіб зв'язок із Джоном Ленгдоном зберігається, однак декодувати цей зв'язок, як і в оригіналі, може лише людина, що знайома 3 його творчістю.

Помічника Лі Тібінга звуть Rémy Legaludec [6]. Ім’я останнього асоціюється з назвою відомого бренду французького коньяку Rémy Martin. Оскільки Ремі отруївся коньяком, до якого було домішано алерген у вигляді арахісового порошку, імовірно, письменник обирає антропонім для відображення цієї ситуації. У перекладі ім'я транслітеровано як Ремі Легалудек [4] або ж передано практичною транскрипцією Ремі Легалюдек [5], тож в обох випадках ім'я Ремі звучить так само, як в оригіналі. Однак розглянемо розповсюдження коньяку "Rémy Martin": його постачали до США ще з 1937 року, тимчасом як до України він міг потрапити лише в останні роки існування Радянського Союзу. Отже, очевидно, що, хоча цей коньяк наразі відомий в обох країнах, у США він є більш популярним, і англомовному читачеві буде простіше декодувати послання автора. 
Серед антропонімів зі значущим словом у своєму складі в ідіоономастиконі Дена Брауна виділяємо ім'я головної героїні роману “Код да Вінчі” Sophie Neveu, зміст якого пояснено в тексті роману: дідусь героїні (Жак Соньєр) завжди жартував, що дівчина $\epsilon$ напівбожеством, бо в ії імені $\epsilon$ літери PHI: "Of course. The Divine Proportion." Her expression turned sheepish. "In fact, he used to joke that I was half divine... you know, because of the letters in my name." Langdon considered it a moment and then groaned. s-o-PHI-e [6, c. 130]. Число Phi позначає закон, що лежить в основі побудови багатьох живих і неживих об’єктів, його можна отримати внаслідок відношення, яке називають Золотою пропорцією (в англійській мові - the golden ration або divine proportion). Така асоціація набуває нового значення наприкінці роману, коли стає відомо, що дівчина $є$ прямим нащадком Ісуса Христа.

Завдяки транскрипції перекладачам удається віднайти відповідник, що дає змогу передати зв’язок із числом Phi / pi-Coфpi: “Ззичайно. Це так звана божественна пропориія. - Вона ніяково всміхнулася. - Він навіть жартував, щзо я напівбожество... ну, через те, що в моєму імені є ичі літери.” Якусь мить Ленгдон ие обмірковував, а тоді зрозумів. Со-фрi [4, с. 96] або “Звичайно! Золотий перетин! - раптом на ї̈ обличчі відбилося зніяковіння. - Він часто жартував, щуо я також наполовину богиня ... через ті літери, з яких складається моє ім'я.” Лентдон на якусь мить замислився, а потім протягнув: “C-o-фpi!" [5, с. 63]. Отже, переклад здійснено із урахуванням пояснення, даного автором тексту щодо імені головної героїні. Як результат, переклад антропоніма $є$ повністю адекватним $з$ огляду на асоціативне навантаження, яке повинно нести в собі це ім'я.

В іменах п'яти головних персонажів роману “Інферно" є літери, що складають слово sin: Elizabeth Sinskey, Sienna Brooks, Jonathan Ferris, Ignazio Busoni [7]. Очевидно, Ден Браун хотів наголосити на темі гріховності, зокрема, на семи смертних гріхах, про які неодноразово письменник згадує в романі. Цікавими $\epsilon$ спостереження Г. Еріксона [12], згідно 3 якими антропоніми, ужиті в четвертому романі циклу про Роберта Ленгдона, приховують назви конкретних гріхів або їхні синоніми: treason (“зрада") в імені Jonathan Ferris

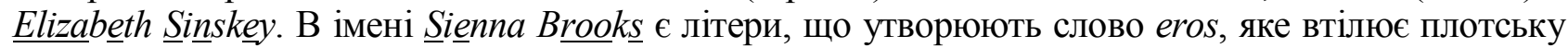
любов або блуд (lust), а в імені Ignazio Bussoni, також відомого як il Duomino, наявні літери латинського gula, що в англійській мові відповідає gluttony (“ненажерливість”) [12, с. 69]. Майже всі вади, зашифровані в іменах, певною мірою характеризують персонажів. Так, Сінскі від своїх ліків тривалий час $є$ доволі слабкою і страждає від запаморочення; Бусоні $є$ занадто товстим; Сієнна згадує про сексуальні стосунки із Цобрістом; Ферріс видає себе не за того, ким $\epsilon$ насправді. У перекладі відповідно: Елізабет Сінскі, Сієнна Брукс, Джсонатан Ферріс, Ітнаціо Бусоні [3], з чого можна зробити висновок про те, що найбільш глибинні значення імен персонажів втрачаються під час перекладу. Однак, з нашого погляду, семантичне наповнення наведених імен можливо зберегти шляхом концентрації уваги на змісті антропонімів, відтворивши їх, наприклад, такими варіантами: Елізабет Сьїнскі (лінь), Соенна Брукс (ерос), Джсонатан Ферріз (зрада), Ітнасіо Бизонте (неситий).

Отже, багато імен персонажів в ідіостилі Дена Брауна не є “порожніми", вони мають значне смислове навантаження, відтворюючи характеристики героїв, створюючи асоціації 3 реальними людьми або втілюючи певні мотиви творів. У зв'язку з цим власні назви дійових осіб у художніх творах письменника $\epsilon$ допоміжним елементом розкриття образу та ідейнотематичного змісту. У багатьох випадках читач мусить самостійно аналізувати семантику антропонімів задля з'ясування тонкощів, які автор приховує.

Проведений аналіз дозволяє стверджувати, що промовисті імена персонажів у творах Дена Брауна є справжнім викликом для перекладача. Оскільки дії у творах письменника відбуваються у звичайному світі (на відміну від казкового, де імена персонажів можуть передаватися зі збереженням семантики їх компонентів), перекладач прив'язаний до антропонімікону реального світу, через що виникають значні втрати під час перекладу. Тому перекладач стикається із проблемою щодо того, чим варто пожертвувати під час перекладу: для передачі закодованих в іменах смислів недостатньо просто транскрипції / транслітерації, тому що такі смисли може бути втрачено, однак водночас він не може обмежитися і буквальним 
перекладом або застосуванням лексико-семантичних трансформацій, відтворюючи значення компонентів імені, оскільки це призведе до прирощування додаткових смислів або спотворення ідіостилю автора. Проаналізовані переклади творів Д. Брауна демонструють, що перекладачі В. К. Горбатько, А. Б. Кам'янець та Є. А. Кононенко мають спільний підхід до відтворення антропонімікону автора в перекладі - всі вони прагнуть максимально точно передати поєднання змісту та форми антропоніму, однак у деяких випадках жертвують змістом заради збереження форми такої одиниці, оскільки вона повинна відповідати антропонімікону реального світу.

Висновки. У своїх романах Ден Браун використовує значну кількість промовистих власних імен, символізм яких є однією із визначальних рис ідіостилю письменника. Кожне із таких імен - це загадка, яку читачеві потрібно розв'язати, тому їх відтворення при перекладі надзвичайно важливе не лише для збереження мовного оформлення твору, а і для адекватної передачі творчого задуму автора. В українськомовних перекладах більшість таких імен передано засобами транскрипції або транслітерації, і українські перекладачі свідомо обирають стратегію форенізації власних імен, жертвуючи частиною смислів, закладених у них, задля збереження основного художнього задуму письменника. Проведене дослідження демонструє, що досягнення балансу між значенням та формою власного імені під час перекладу художніх творів різних жанрів досі постає актуальною проблемою сучасного перекладознавства, що вимагає подальших пошуків.

\section{References:}

1. Arutiunova, Nina. 1977. "Nomynatsyia, referentsyia, znacheniie". Yazykovaia nomynatsyia (Obshchiie voprosy). Moskwa 230-293.

2. Belei, Liubomyr. 1995. Funktsionalno-stylistychni mozhlyvosti ukrainskoi literaturno-khudozhnoi antroponimii $X I X-X X$ st. Uzhhorod: Patent.

3. Braun, Den. 2018. Inferno. Kharkiv.

4. Braun, Den. 2006. Kod da Vinchi. Kharkiv.

5. Braun, Den. 2017. Kod da Vinchi. Kharkiv.

6. Brown, Dan. 2004. The Da Vinci Code. London: Corgi.

7. Brown, Dan. 2014. Inferno. London: The Random House Group Ltd.

8. Byriukova, Oksana. 2009. "Tekstoobrazuyushchiye funktsii imen sobstvennykh v aspekte idiostilya: (na materiale korotkikh angloyazychnykh rasskazov XX veka)". Phd diss., Novgorod.

9. Chernyk, Olena. 2018. "Linhvostylistychni osoblyvosti zahadok v tvorakh Dena Brauna z tsyklu pro Roberta Lengdona”. Linhvistyka. Linhvokulturolohiia 12(1): 297-312.

10. Collins English Dictionary. https://www.collinsdictionary.com/dictionary/english.

11. Dan Brown Witness Statement in The Da Vinci Code Case. 2006. The Times https://www.thetimes.co.uk/article/dan-brown-witness-statement-in-da-vinci-code-case-5cvdjhkvmbn.

12. Erickson, Glenn. 2013. "Letting the genre out of the bottle: Dan Brown's Inferno as modern parody". Secrets of Inferno: in the footsteps of Dante and Dan Brown. Stamford: Story Plant 67-77.

13. Gorbunova, Anastasiya. 2010. "Osobennosti yazyka i stilya Dena Brauna v aspekte perevoda". PhD diss., Moskwa.

14. Hera, Oksana. 2007. "Vlasni nazvy v ukrayinskomu perekladi knyh pro Harri Pottera Dzh. K. Roling". Inozemna filolohiya 119 (2): 134-140.

15. Kapnina, Halyna. 2014. "Vidtvorennia antroponimiv u protsesi perekladu kazok (na materiali nimetskoho ta ukrainskoho folkloru)". Naukovi zapysky Natsionalnoho universytetu Ostrozka akademiia. Seriia: Filolohichna 45: 247-249.

16. Karpenko, Yuriy. 2002. "Pro literaturnu onomastyku: Mirkuvannya na bazi tvoru Liny Kostenko «Korotko yak diahnoz»”. Linguistica slavica 75-83.

17. Lamping, Dieter. 1983. Der Name in der Erzahlung. Zur Poetik des Personennamens. Bonn: Bouvier Verlag Herbert Grundmann.

18. Lipgart, Andrey. 2007. Parody and Style: On "The Da Vinci Code” by Dan Brown, "The Asti Spumante Code" by Toby Clements and "The Va Dinci Cod" by A. R. R. R. Roberts. Moskva: KomKniga.

19. Morozova, Evgeniya. 2010. "Yavleniye pretsedentnosti v romanakh D. Brauna: funktsionalnyi i kulturologicheskiy aspekty”. PhD diss., Stavropol.

20. Nekriach, Tetiana. 2019. Trudnoshchi vidtvorennia u perekladi vlasnykh imen z prozoroiu semantykoiu http:/www.t-fishing.co.ua/events/articles/trudnoshchi-vidtvorennya-u-perekladi-vlasnykh-imen-z-prozoroyusemantykoyu/.

21. Pavliuk, Alla. 2014. "Osoblyvosti perekladu vlasnykh nazv z angliiskoi movy ukrainskoiu u romani Charlza Dikkensa «Posmertni zapysky Pikvikskogo klubu»". Naukovi zapysky NDU im. M. Hoholia. Filologichni nauky 3: 135-138. 
22. Pindosova, Tamara. 2019. "Katehoriia intertekstualnosti v khudozhnikh tekstakh D. Brauna: prahmastylistychnyi aspekt". PhD diss., Kherson.

23. Rennes-le-Château Research and Resource. http://www.renneslechateau.nl/mystery-of-rennes-le-chateau/.

24. Revzina, Olga. 1991. "Sobstvennyie imena v poeticheskom idiolekte M. Tsvetaevoy". Poetika i stilistika 19881990 1: 172-192.

25. Slovar konnotativnykh sobstvennykh imen. 2010. Donetsk: Yugo-Vostok.

26. Stasiuk, Bohdan. 2009. "Nepovnoekvivalentnist vlasnykh nazv (na materiali ukrainskoho perekladu kazkovoi povisti Dzh. R. Tolkina «Farmer Giles of Ham»”. Naukovyi visnyk Khersonskoho derzhavnoho universytetu. Seriia Linhvistyka 10: 209-214.

27. Uryvalkin, Oleksandr. 2006. Istorychne kraieznavstvohttp://pidruchniki.ws/12810419/kulturologiya/ antroponimika ukrayini.

28. Yaschuk, Olhā. 2012. "Osoblyvosti pereklady anhliiskykh vlasnykh nazv”. Dostizheniya nauki za posledniye gody. Novyye narabotki http://конференция.com.ua/files/image/konf\% 2012/doklad_12_5_29.pdf.

Черник Елена. «Говорящие» имена в идиостиле Дэна Брауна как проблема перевода. В статье проведен анализ способов передачи «говорящих» имен персонажей в творчестве Дэна Брауна в украиноязычных переводах. Рассмотрены преимущества и недостатки этих методов с целью выявления ключевых проблем, с которыми сталкиваются переводчики при передаче антропонимикона произведений писателя. Автор статьи утверждает, что использование «говорящих» имен персонажей является одной из определяющих черт идиостиля Дэна Брауна, творческий метод которого заключается в создании интеллектуальной игры между автором и читателем, атмосферы загадочности и таинственности, а также в придаче символического смысла описываемым явлениям. «Говорящие» имена содержат указание на судьбу, характер персонажа или даже на развязку загадки целого произведения. На основе переводов произведений Дэна Брауна “Код да Винчи” и “Инферно” такими украинскими переводчиками, как В. К. Горбатько, А. Б. Каменец и Е. А. Кононенко, основными средствами передачи «Говорящих» имен персонажей в произведениях писателя определено транскрипцию и транслитерацию, которые позволяют достичь адекватного перевода. Сделан вывод о том, что адекватность такого перевода заключается в создании баланса между формой и значением антропонима, поскольку в некоторых случаях просто невозможно одновременно сохранить и форму, и содержательное наполнение единицы. Эта ситуация приводит к тому, что переводчик стоит перед дилеммой: с одной стороны, транскрипции / транслитерации недостаточно для полной передачи «говорящего» имени, потому что закодированные в нем смыслы могут быть утеряны, а с другой переводчик не может ограничиться лишь передачей значения единицы, поскольку это приведет как к потере формы, так и к приращению дополнительных смыслов или искажению идиостиля автора. Исследование акцентирует внимание на том факте, что каждое из «говорящих» имен, использованных Дэном Брауном в его произведениях, это загадка для читателя, которую переводчик должен передать и читателю произведения на языке перевода. Сделан вывод о том, что украинские переводчики осознают это, однако вынуждены жертвовать частью заложенных в именах смыслов ради сохранения основного художественного замысла писателя.

Ключевые слова: антропоним, загадка, смысловая нагрузка, транскрипция, транслитерация, форенизация.

Chernyk Olena. Speaking Names in Dan Brown's Idiostyle as a Translation Issue. The article deals with the ways of rendering characters' speaking names in Dan Brown's works into the Ukrainian language. The author analyses the advantages and disadvantages of these ways in order to identify the key challenges that translators face when conveying anthroponymics in the writer's works. The author of the article determines that the use of speaking names of the characters is one of the defining features of Dan Brown's individual style as the creative method of the writer is to invent an intellectual game between the author and the reader, to establish the atmosphere of mystery as well as to impart a symbolic meaning to the phenomena described. Speaking names contain an indication on the fate, nature of the character or even on the solution to the puzzle of the whole book. Based on Dan Brown's works The Da Vinci Code and Inferno translated by such Ukrainian translators as V. K. Gorbatko, A. B. Kamyanets, and Ye. A. Kononenko, transcription and transliteration, which allow achieving adequate translation, were determined as the basic means of rendering the characters' speaking names. It was concluded that the adequacy of such translation is in creating a balance between the form and the meaning of the anthroponym since in some cases it is simply impossible to preserve both the form and the meaning of the unit. This situation makes the translator face a dilemma: on the one hand, transcription / transliteration is not enough to fully reproduce the speaking name as the meanings "encoded" in it can be lost, on the other hand, the translator cannot limit himself only to the reproduction of the meaning of the unit, for this leads to the loss of the form as well as to creating additional meanings or distorting the author's idiostyle. The study concentrates attention on the fact that each of the speaking names used in Dan Brown's works is a puzzle for the reader, and the translator must convey it to the reader of the target language text. The author comes to conclusion that Ukrainian translators are aware of this fact, but they are forced to sacrifice some of the meanings embodied in the names for the sake of preserving the writer's basic artistic intent.

Keywords: anthroponym, puzzle, message, transcription, transliteration, foreignization. 